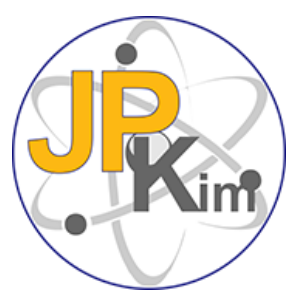

Jurnal Pendidikan Kimia

Vol. 13 | No. 2 |94 - 102| August | 2021

ISSN: 2085-3653| e-ISSN: 2549-3116

https://jurnal.unimed.ac.id/2012/index.php/jpk

https://jurnal.unimed.ac.id

\title{
Improving chemical learning outcomes with explicit instruction learning models with quizizz evaluation media
}

\author{
Bropson Minanlarat ${ }^{1}$, Leony Sanga Lamsari Purba ${ }^{1, *}$ and St Fatimah \\ Azzahra' \\ ${ }^{1}$ Department of Chemistry Education, Faculty of Teacher Training and Education, Universitas Kristen \\ Indonesia, Jakarta 13630, Indonesia \\ *Corresponding author: LSLP, leony.purba@uki.ac.id
}

DOI: 10.24114/jpkim.v13i2.26977

Article history:

Received: 15 May 2021

Revised: 09 July 2021

Accepted: 15 July 2021

\begin{abstract}
This study aims to determine the effect of explicit instruction learning models and the percentage of student learning outcomes improvement in chemistry. Explicit instruction learning model is the free variable while the dependent variable is learning outcomes. This research method is a quasi experiment with the research design nonequivalent control group design. The population of this study were students of Senior High School 42 Jakarta, the sample was selected by purposive sampling technique, consisting of two classes, namely class XI MIA 1 as the experimental class and XI MIA 2 as the control class. The results of the ttest show that the sig. (2-tailed) is smaller than the $a$ value, namely sig $0.000<$ sig 0.05 , so learning using the explicit instruction model has a significant effect on improving chemistry learning outcomes on hydrocarbon compound material. In addition, the use of explicit instruction learning models can improve student learning outcomes by $19 \%$ when compared with the use of conventional learning models $(\mathrm{TCL})$.
\end{abstract}

Keywords: Explicit instruction, Quizizz, Chemistry learning, Learning outcomes

\section{Introduction}

Competition in chemistry learning in the world is increasing in the era of technology 5.0. The results of the Asian level chemistry Olympiad prove that all countries are competing to become champions, including representative students from Indonesia (Purba et al. 2021). Teachers as a profession must be able to show their existence in contributing to competition in the global era. Competition in the global era was increasingly felt in the Covid-19 pandemic era (Gunawan et al. 2021), which resulted in a significant change in learning patterns from offline to online (Ichsan et al. 2021; Novira et al. 2021). 
The paradigm of students towards online learning in chemistry subjects is different. Based on the results of a questionnaire distributed to students of Senior High School 42 Jakarta, $73.5 \%$ of the 34 respondents stated that they were interested in learning chemistry because chemistry is an interesting subject, it can be applied in everyday life and they also realize the importance of chemistry for the future. ahead of them. However, $61.8 \%$ of students stated that they felt bored during the learning process, because learning was teacher centered. According to Siahaan et al. (2021), teacher centered learning still dominates the learning carried out by teachers.

Innovation in the learning process is an important thing that must be considered by teachers so that teachers can facilitate students in learning (Silaban, 2021). According to Silaban (2017) paying attention to the learning model is an effort to adjust the steps of learning with learning tools including books, films, computers, curricula. Various kinds of learning models can be used to improve the quality of learning (Junita \& Purba, 2019; Purba 2017), but Arends (2001) argues that there is no one learning model that is the best among the others, because each learning model can be felt good, if it has been tested to teach certain subject matter. There are several kinds of learning models, one of which is the explicit instruction learning model (Anwar \& Lapenia, 2019). The explicit instruction learning model is a teaching approach designed for procedural knowledge, declarative knowledge and various skills (Komala, 2017), which helps students learn basic skills and obtain information that can be taught step by step (Silviana, 2016). This learning model is often called direct learning (Silma, 2017).

The advantages of this explicit instruction learning model are being able to control important points or difficulties that students may face during the learning process (Putri et al. 2017), equipping students with disciplinary ways to view the world using alternative perspectives. "Which makes students aware of the limited perspective inherent in everyday thinking (Sihombing, 2019). Besides having advantages, explicit instruction learning model also has weaknesses. One of the advantages of this model is that active students have less space to develop their social competence (Mastika et al. 2013).

Various efforts to improve student abilities are without exception the teacher's attention (Prastiwi \& Nurita, 2018). The step that can be done is by combining learning models with learning media (Sihombing et al. 2020). Learning models can be maximized if applied with the help of media to significantly improve learning outcomes (Mansur, 2018; Pujiyati, 2017), and (Metroyadi \& Mardiah, 2018). Various learning media tools can be accessed free of charge by students and teachers (Saputro \& Lumbantoruan, 2020). There are learning media such as quizizzes (Harefa, et al. 2020); kahoot (Purba, 2019). Each of these media has strengths and weaknesses (Cahyani, 2021; Musyayadah, 2019). In this study, using quizizz media by considering the advantages of quizizz, namely the existence of a leaderboard which provides an opportunity for all students to find out the grades and ratings of all students who took the quiz, thus motivating students to maximize their abilities during the quiz (Amri \& Sobri, 2020).

The use of media quizzes which is assisted in the explicit instruction learning model when learning colloids considers the characteristics of hydrocarbon material which are quite theoretical. Hydrocarbons are abstract chemical materials and need a high level of understanding, so that models and learning media that are not appropriate often students' scores are not optimal (Qurniawati \& Saputro, 2013). With the use of explicit instruction 
learning model assisted by media quizzes, it is hoped that it will be effective to improve student learning outcomes on the subject of hydrocarbons.

\section{Methods}

The research design with the quasi-experimental method was nonequivalent control group design, meaning that the two groups selected in this study were one experimental group and one control group (Sugyono, 2017). The research design is presented in Table 1.

Table 1

Research Design

\begin{tabular}{l|c|c|c}
\hline \multicolumn{1}{c|}{ Group } & Pretest & Treatment & Posttest \\
\hline Experiment & $\mathrm{O} 1$ & $\mathrm{X}$ & $\mathrm{O} 2$ \\
\hline Control & $\mathrm{O} 1$ & $\mathrm{~K}$ & $\mathrm{O} 2$ \\
\hline
\end{tabular}

Information: $\mathrm{X}$ : Treatment using explicit instruction learning model; K: Using conventional learning models; $\mathrm{O}_{1}$ : Pretest of the experimental group and the control group; $\mathrm{O}_{2}$ : Posttest experimental group and control group

The population in this study were students of Senior High School 42 Jakarta in the even semester of the 2018/2019 academic year and the odd semester of the 2019/2020 school year. As for the sample to be examined in this study were students of class XI MIA Senior High School 42 Jakarta. The sampling technique was carried out in this study using a nonprobability sampling technique with a purposive sampling method because of the difficulty of determining the class XI student learning schedule. In this study, the two classes selected were class XI MIA 1 as the experimental group and class XI MIA 2 as the control group.

To collect research data, a research instrument was prepared in the form of a test instrument in the form of multiple choice questions with options $A, B, C, D$ and $E$. The instruments were arranged according to the indicators of hydrocarbon material. Before the instrument was used, the question instrument validation test was carried out with the expert judgment validation technique or the opinion of an expert, namely the lecturer of chemistry education, Faculty of Teacher Training and Education UKI Jakarta. From the validation results, from 40 questions obtained 30 valid questions. All 30 valid questions were used as instruments in the study.

Before analyzing the research data, a prerequisite test was carried out, namely the Kolmogorov Smirnov normality test (normal data if the significance value (Sig.) Is less than 0.05) and Leneve's homogeneity test (homogeneous data if the significance value (Sig.) Is greater than 0.05). Furthermore, analysis is carried out by testing the hypothesis. Hypothesis testing is used to determine the effect of experimental methods and explicit instruction models on improving student learning outcomes. Hypothesis testing in this study using the $T$ test.

$T$ test results can be seen if the value of Sig. (2-tailed) $<0.05$ then the hypothesis is proven, meaning that $\mathrm{Ho}$ is rejected and $\mathrm{Ha}$ is accepted. The hypothesis proposed in this study is:

$\mathrm{Ho}$ : There is no significant effect of explicit instruction learning model on student learning outcomes of class XI on hydrocarbon compound material. 
$\mathrm{Ha}$ : There is a significant effect of explicit instruction learning model on student learning outcomes of class XI on hydrocarbon compound material.

Statistical hypothesis:

If $t_{\text {table }}<t_{\text {count }}$ then $\mathrm{Ho}$ is accepted and $\mathrm{Ha}$ is rejected.

If $+t_{\text {tabel }}>t_{\text {count }}$ then $\mathrm{Ho}$ is rejected and $\mathrm{Ha}$ is accepted.

To find out the magnitude of the increase, a gain test is carried out, which will be interpreted according to Table 2.

Table 2

Classification of Gain Index

\begin{tabular}{c|c}
\hline Score Gain & Interpertation \\
\hline $0.71-1.00$ & High \\
\hline $0.31-0.70$ & Medium \\
\hline $0-0.30$ & Low \\
\hline
\end{tabular}

The percentage of the gain test is\% of the results of the gain test = the value of the gain test $\times 100 \%$. The prerequisite test analysis and data analysis test were carried out with the help of SPSS 23.

\section{Results and Discussion}

Based on the results of the control class pretest and the experimental class above, it is clear that the learning outcome scores owned by the students in the two classes are not different. This is because students in both classes are still in the initial knowledge stage, namely the extent to which students have knowledge about the hydrocarbon compound material taught by the teacher. Based on the research results, the pretest results were obtained as presented in Table 3.

Table 3

Pretest Results

\begin{tabular}{c|c|c}
\hline Statistic & $\begin{array}{c}\text { Pretest } \\
\text { Control }\end{array}$ & $\begin{array}{c}\text { Posttest } \\
\text { Experiment }\end{array}$ \\
\hline $\mathrm{N}$ & 32 & 32 \\
\hline Mean & 39.84 & 39.35 \\
\hline Median & 40.00 & 40.00 \\
\hline Std. Deviation & 9.35 & 8.73 \\
\hline Variance & 87.47 & 76.24 \\
\hline Range & 35 & 35 \\
\hline Minimum & 20 & 20 \\
\hline Maximum & 55 & 55
\end{tabular}

Based on the table above, the mean value for the control class pretest is 39.84 and the experimental class is 39.35. From these data, it can be seen that the initial abilities of the experimental and control class students are the same.

Furthermore, after being given the treatment of each sample according to the RPP, the posttest result data were obtained as presented in Table 4. 
Table 4

Posttest Result

\begin{tabular}{c|c|c}
\hline Statistic & $\begin{array}{c}\text { Posttest } \\
\text { Control }\end{array}$ & $\begin{array}{c}\text { Posttest } \\
\text { Experiment }\end{array}$ \\
\hline $\mathrm{N}$ & 32 & 32 \\
\hline Mean & 71.13 & 80.32 \\
\hline Median & 70.00 & 80.00 \\
\hline Std. Deviation & 6.02 & 7.30 \\
\hline Variance & 36.18 & 53.23 \\
\hline Range & 30 & 30 \\
\hline Minimum & 55 & 60 \\
\hline Maximum & 85 & 90
\end{tabular}

Based on the table above, the average value of the control class is 71.13 and the experimental class is 80.32 . From these data, it can be seen that the final abilities of the experimental and control class students are different.

The pretest result data was tested for normality with SPSS 23 and the results were as shown in Table 5. Based on the data above, it was found that the data were normally distributed because the two classes were sig $<0.05$. After the normality test is carried out, the next prerequisite test is carried out, namely the homogeneity test with SPSS 23 and the results are as presented in Table 6.

Table 5

Results of Normality Test

\begin{tabular}{c|c|c|c}
\hline \multirow{2}{*}{ Class } & \multicolumn{3}{|c}{ Kolmogorov-Smirnov $^{\mathrm{a}}$} \\
\cline { 2 - 4 } & Statistic & Df & Sig. \\
\hline Experiment & 0.153 & 31 & 0.006 \\
\hline Control & 0.120 & 31 & $0.020^{*}$ \\
\hline
\end{tabular}

Table 6

Homogeneity Test Results

\begin{tabular}{c|l|c|c|c|c}
\hline \multicolumn{2}{l|}{} & $\begin{array}{c}\text { Levene } \\
\text { Statistic }\end{array}$ & $\mathrm{df1}$ & $\mathrm{df2}$ & Sig. \\
\hline \multirow{2}{*}{$\begin{array}{c}\text { Learning } \\
\text { Outcome } \\
\text { Based on }\end{array}$} & Mean & 1.59 & 1 & 60 & 0.21 \\
\cline { 2 - 6 } & Median & 1.79 & 1 & 60 & 0.18 \\
\cline { 2 - 6 } & Median and with adjusted df & 1.79 & 1 & 59.98 & 0.18 \\
\cline { 2 - 6 } & Trimmed Mean & 1.66 & 1 & 60 & 0.20 \\
\hline
\end{tabular}

Based on the data above, it is found that the data is homogeneous because in both classes sig $>0.05$. Furthermore, the data analysis test was carried out using SPSS 23, namely the tpaired test to test the hypothesis. Based on data analysis, the results obtained are as presented in Table 7. 
Table 7

t-Paired Test Result

\begin{tabular}{|c|c|c|c|c|c|c|c|c|}
\hline \multirow{3}{*}{ T-Test } & \multicolumn{5}{|c|}{ Paired Differences } & \multirow{3}{*}{$\mathrm{T}$} & \multirow{3}{*}{$\mathrm{df}$} & \multirow{3}{*}{$\begin{array}{l}\text { Sig. (2- } \\
\text { tailed) }\end{array}$} \\
\hline & \multirow[t]{2}{*}{ Mean } & \multirow[t]{2}{*}{$\begin{array}{c}\text { Std. } \\
\text { Deviation }\end{array}$} & \multirow[t]{2}{*}{$\begin{array}{l}\text { Std. } \\
\text { Error } \\
\text { Mean }\end{array}$} & \multicolumn{2}{|c|}{$\begin{array}{l}\text { 95\%Confidence } \\
\text { Interval of the } \\
\text { Difference }\end{array}$} & & & \\
\hline & & & & Lower & Upper & & & \\
\hline $\begin{array}{l}\text { Pretest } \\
\text { Posttest }\end{array}$ & -40.96 & 6.24 & 1.122 & -43.25 & -38.67 & -36.51 & 30 & 0.000 \\
\hline
\end{tabular}

The results of the paired samples test show the tcount value of 36.510 with a digre freedom (df) 30. In addition, the table above also shows the sig. (2-tailed) value of 0.000 . Based on the statistical $t$ test, if the value of $t$ count $>t$ table or the value of sig. (2-tailed) $<a$ $=0.05$ then $\mathrm{Ho}$ is rejected and $\mathrm{Ha}$ is accepted. Given that the ttable value for $\mathrm{df} 30$ is 2.042 . Based on these data, it is known that $t_{\text {count }} 36.510>t_{\text {table }} 2.042$ and sig. (2-tailed) $0.000<\alpha=$ 0.05 , it can be stated that $\mathrm{Ho}$ is rejected and $\mathrm{Ha}$ is accepted. Thus the posttest results in this study can test the truth of the hypothesis, so that the alternative hypothesis ( $\mathrm{Ha}$ ) which states that there is a significant effect of the explicit instruction learning model on student learning outcomes is accepted. So that this research can show that learning using explicit instruction learning models can improve student learning outcomes on the subject matter of hydrocarbon compounds.

Furthermore, to find out how to improve student learning outcomes, a gain test is carried out. After obtaining the results of the pretest and posttest in the two classes, then the calculation of the difference between the pretest and posttest results is carried out to determine the effect of the learning model. The results of the gain test for the control class and experimental class can be seen in Table 8.

Table 8

Gain Test Results

\begin{tabular}{c|c|c}
\hline Class & Gain Test Result & Information \\
\hline Control & 0.51 & Medium \\
\hline Experiment & 0.72 & High \\
\hline
\end{tabular}

Based on the table above, it is known that the gain value for the control class is 0.51 and for the experimental class is $\mathbf{0 . 7 2}$. If the gain value of the two classes is interpreted into the gain index classification, then the control class is included in the medium criteria while the experimental class is included in the high criteria. So it can be concluded that the increase in student learning outcomes in the experimental class using the explicit instruction learning model is higher than the control class that uses the conventional learning model. As for the percentage gain test for the experimental class is $0.72 \times 100 \%=72 \%$ and for the control class is $0.5 \times 100 \%=50 \%$.

The increase in student learning outcomes in the high category is the output of developing student knowledge in a procedural and declarative manner by applying the Explicit Intruction model, which is one step so that students can understand and truly know knowledge thoroughly and actively in learning regularly, step by step. stages (Yasa, 2012), as 
well as the assistance of quizizz learning media which can increase achievement motivation in students (Noor, 2020).

\section{Conclusion}

There was a significant increase in the learning outcomes of chemistry by using the explicit instruction learning model with the help of the quizizz learning media.

\section{Acknowledgment}

Researchers would like to thank the Universitas Kristen Indonesia for providing facilities for the implementation of this research.

\section{References}

Amri, M., \& Shobri, Y. A. (2020). Persepsi mahasiswa terhadap penggunaan quizizz dalam pembelajaran akuntansi konsolidasi Bank Syariah di IAIN Ponorogo. Jurnal Teknologi Informasi dan Pendidikan, 13(1), 128-136. DOl:10.24036/tip.v13i1.301

Anwar, A. S., \& Lapenia, P. (2019). Penerapan model pembelajaran explicit instruction Untuk meningkatkan hasil belajar siswa pokok Bahasan cahaya dan sifatnya pada siswa kelas $v$ di SD Negeri 1 sembawa. Jurnal Lensa Pendas, 4(1), 52-59. DOl:10.33222/jlp.v4i1.488

Arends, R.I. (2001). Exploring Teaching: An Introduction to Education. New. York: Mc Graw-Hill Companies.

Cahyani, R. R. (2021). Pengembangan soal tes berbasis quizizz sebagai alat evaluasi untuk menumbuhkan motivasi berkompetisi peserta didik (Doctoral dissertation, UIN Sunan Ampel Surabaya).

Gunawan, G., Purwoko, A. A., Ramdani, A., \& Yustiqvar, M. (2021). Pembelajaran menggunakan learning management systemberbasis moodle pada masa pandemi covid-19. Indonesian Journal of Teacher Education, 2(1), 226-235.

Harefa, N., Sinaga, M., \& Silaban, S. (2020). Students perception and interest on chemistry: Learning evaluation integrated quizziz media. Jurnal Pendidikan Kimia, 12(3), 143-150. DOI:10.24114/jpkim.v12i3.21163

Ichsan, I. Z., Rahmayanti, H., Purwanto, A., Sigit, D. V., Kurniawan, E., Dewi, A. K., ... \& Marhento, G. (2020). Covid-19 dan E-Learning: Perubahan strategi pembelajaran sains dan lingkungan di SMP. JINoP (Jurnal Inovasi Pembelajaran), 6(1), 50-61. DOI:10.22219/jinop.v6i1.11791

Komala, E. (2017). Mathematical resilience mahasiswa pada mata kuliah struktur aljabar I menggunakan pendekatan explisit instruction integrasi peer instruction. Mosharafa: Jurnal Pendidikan Matematika, 6(3), 357-364. DOI:10.31980/mosharafa.v6i3.324

Jati, D. H. P. (2020). Peningkatan hasil belajar ppkn melalui pembelajaran online berbasis quizizz. eJurnal Mitra Pendidikan, 4(5), 231-240. DOI:10.52160/e-jmp.v4i5.737

Junita, Y., \& Purba, L. S. L. (2019). Peningkatan hasil belajar kimia siswa melalui model pembelajaran kooperatif tipe think pair share (tps) di SMAN 92 Jakarta. Jurnal Dinamika Pendidikan, 12(1), 41-54. DOI:10.51212/jdp.v12i1.1029

Mansur, M. (2018). Pengaruh model pembelajaran explicit instruction berbantuan media gambar terhadap hasil belajar IPA. Ibtida'i: Jurnal Kependidikan Dasar, 5(1), 15-28. DOI:10.23887/jjpgsd.v111.755

Mastika, L. A. D., Jampel, I. N., \& Kusmariyatni, N. (2013). Pengaruh model pembelajaran explicit instruction berbantuan media gambar terhadap hasil belajar IPA kelas V SD gugus I Kecamatan Buleleng. MIMBAR PGSD Undiksha, 1(1). DOI:10.23887/jjpgsd.v1i1.755 
Metroyadi, M., \& Mardhiah, A. (2018). Efforts to develop children fine motor skills through sticking picture properly by using combination of explicit instruction model and assignment media utilizing natural materials. Journal of K6 Education and Management, 1(2), 19-24. DOI:10.11594/jk6em.01.02.04

Musyayadah, N. (2019). Pengembangan instrumen tes fisika kelas xi materi alat-alat optik melalui pemanfaatan aplikasi quizizz (Doctoral dissertation, UIN Walisongo)

Noor, S. (2020). Penggunaan quizizz dalam penilaian pembelajaran pada materi ruang lingkup biologi untuk meningkatkan hasil belajar siswa kelas X. 6 SMAN 7 Banjarmasin. Jurnal Pendidikan Hayati, 6(1), 1-7. DOI: 10.33654/jph.v1i1.927

Novira, P., Silalahi, A., \& Silaban, S. (2021). Analysis effectiveness of the online learning through the use of google classroom during the Covid-19 pandemic. Jurnal Pendidikan dan Pembelajaran Kimia, 10(1), 88-93. DOI: 10.23960/jppk.v10.i1

Prastiwi, M. D., \& Nurita, T. (2018). Kemampuan pemecahan masalah pada siswa kelas VII SMP. PENSA E-JURNAL: Pendidikan Sains, 6(02), 98-103.

Pujiyati, S. F. (2017). Penerapan model explicit instruction berbantuan media petak perkalian dalam materi ajar kelipatan dan faktor suatu bilangan. Didaktikum: Jurnal Penelitian Tindakan Kelas, 18(1), 20-25.

Purba, L. S. L. (2017). Pengaruh penerapan model pembelajaran kooperatif tipe two stay-two stray (TS-TS) terhadap hasil belajar dan aktivitas belajar siswa pada pokok bahasan koloid. EduMatSains: Jurnal Pendidikan, Matematika dan Sains, 1(2), 137-152. DOI:10.33541/edumatsains.v1i2.239

Purba, L. S. L. (2019). Peningkatan konsentrasi belajar mahasiswa melalui pemanfaatan evaluasi pembelajaran quizizz pada mata kuliah kimia fisika I. Jurnal Dinamika Pendidikan, 12(1), 29-39. doi: 10.51212/jdp.v12i1.1028

Purba, L. S. L., Harefa, N., Afridika, S., \& Savera, D. (2021). The differences of achievement of the national olympiad in chemistry at the public and private senior high school by utilizing quizizz media. Jurnal Pendidikan Kimia, 13(1), 69-77. DOI: 10.24114/jpkim.v13i1.24146

Purba, L. S. L., Sormin, E., \& Harefa, N. (2019). Effectiveness of use of online games kahoot! chemical to improve student learning motivation. Jurnal Pendidikan Kimia, 11(2), 57-66. DOI:10.24114/jpkim.v11i2.14463

Putri, A. M., Arifuddin, M., \& Misbah, M. (2017). Meningkatkan kemampuan analisis dan sikap ilmiah siswa melalui model explicit instruction dengan metode praktikum pada materi ajar listrik dinamis. Vidya Karya, 32(1). DOI:10.20527/jvk.v32i1.4900

Saputro, P. A., \& Lumbantoruan, J. H. (2020). Pengembangan media pembelajaran matematika berbasis articulate storyline pada materi bangun ruang sisi datar kelas VIII. EduMatSains: Jurnal Pendidikan, Matematika dan Sains, 1(1), 35-49. DOI:10.33541/edumatsains.v1i1.2453

Siahaan, R., Sitorus, M., \& Silaban, S. (2021). The development of teaching materials oriented to critical thinking skills for chemistry class XI high school. Jurnal Pendidikan Kimia, 13(1), 60-68. DOI: 10.24114/jpkim.v13i1.24145

Silma, E. (2017). Pengaruh penerapan model pembelajaran explicit instruction terhadap motivasi dan hasil belajar siswa kelas XI IPS pada pelajaran ekonomi (akuntansi) di SMAN 1 Langgam Kabupaten Pelalawan. PEKBIS (Jurnal Pendidikan Ekonomi dan Bisnis), 9(1), 68-76.

Sihombing, D. Y. I. W. (2019). Pengaruh model pembelajaran project based learning dan explicit instruction terhadap hasil belajar siswa pada mata pelajaran kearsipan SMK Negeri 1 Pematangsiantar TA 2019/2020 (Doctoral dissertation, Universitas Negeri Medan).

Sihombing, N. D., Malau, N. D., Guswantoro, T., \& Lumbantobing, S. S. (2020). Penerapan model pembelajaran cooperative learning berbantuan mind map pada siswa kelas XI IPA. EduMatSains: Jurnal Pendidikan, Matematika dan Sains, 1(1), 60-71. DOI:10.33541/edumatsainxs.v111.2460 
Silaban, S. (2017). Dasar-dasar pendidikan matematika dan ilmu pengetahuan alam. Medan: Harapan Cerdas Publisher.

Silaban, S. (2021). Pengembangan program pengajaran. Medan: Yayasan Kita Menulis.

Silviana, G. (2016). Penggunaan model explicit instruction untuk meningkatkan keterampilan generik sains siswa pada konsep biosafety (Doctoral dissertation, FKIP UNPAS).

Sugiyono. (2017). Metode penelitian kuantitatif, kualitatif, dan R\&D. Bandung : Alfabeta

Qurniawati, A., \& Saputro, A. N. C. (2013). Efektivitas metode pembelajaran kooperatif tipe numbered head together (nht) dengan media kartu pintar dan kartu soal terhadap prestasi belajar siswa pada materi pokok hidrokarbon kelas $x$ semester genap Senior High School 8 surakarta. Jurnal Pendidikan Kimia, 2(3), 166-174.

Yasa, I. W. A. M. E. (2012). Penerapan model pembelajaran explicit instruction berbantuan cd interaktif untuk meningkatkan aktifitas dan hasil belajar siswa kelas $\mathrm{x}$ multimedia dalam pembelajaran audio digital di SMK TI Bali Global Singaraja. KARMAPATI (Kumpulan Artikel Mahasiswa Pendidikan Teknik Informatika), 1(1), 115-127. 